\title{
A EDUCAÇÃO BRASILEIRA E A CULTURA FOTOGRÁFICA: PARA ALÉM DA IMPRESSÃO
}

\author{
LA EDUCACIÓN BRASILEÑA Y LA CULTURA FOTOGRÁFICA: PARA MÁS ALLÁ \\ DE LA IMPRESIÓN
}

\author{
BRAZILIAN EDUCATION AND THE PHOTOGRAPHIC CULTURE: BEYOND \\ PRINTING
}

\author{
Edson Rodrigues PASSOS ${ }^{1}$ \\ Alboni Marisa Dudeque Pianovski VIEIRA ${ }^{2}$
}

RESUMO: O trabalho de análise com fontes fotográficas constitui um entrave no que se refere aos fundamentos teóricos e metodológicos para entendê-las como linguagem visual, fonte de formação e informação. Nesse sentido, o artigo trata do papel da fotografia como forma de linguagem visual compósita de signos ideológicos; discute a importância das fontes fotográficas como acervo documental, e apresenta formas de se ultrapassar o limiar da leitura instrumental da imagem fotográfica. Justifica-se a pesquisa pela observação concreta da dificuldade de leitura dos alunos diante de textos construídos pela linguagem visual, principalmente, a fotografia. A pesquisa, bibliográfica e documental, com apoio na dialética, fundamentou-se em autores que se opõem à leitura da imagem fotográfica numa perspectiva positivista. Os resultados possibilitaram reconhecer a natureza da imagem fotográfica como fonte histórica visual, que permite superar o recorte cronológico do momento de sua produção e execução.

PALAVRAS-CHAVE: Imagem fotográfica. Linguagem visual. Educação. Método.

RESUMEN: El trabajo de análisis con fuentes fotográficas constituye un obstáculo en relación con los fundamentos teóricos y metodológicos en el sentido de entender la fotografía como lenguaje visual, fuente de formación e información. En ese sentido, el artículo trata de la imagen fotográfica como forma de lenguaje visual compuesto de signos ideológicos; discute la importancia de las fuentes fotográficas como acervo documental y presenta formas de sobrepasar el umbral de la lectura instrumental de la imagen fotográfica. Se justifica la investigación por la observación concreta de la dificultad de lectura de los alumnos ante textos construidos por el lenguaje visual, principalmente, la fotografía. La investigación, bibliográfica y documental, se fundó en autores que se oponen a la lectura de la imagen fotográfica en una perspectiva positivista. Los resultados posibilitaron reconocer la naturaleza de la imagen fotográfica como fuente histórica visual, que permite superar el recorte cronológico del momento de su producción y ejecución.

\footnotetext{
${ }^{1}$ Pontifícia Universidade Católica do Paraná (PUCPR), Curitiba - PR - Brasil. Professor da Secretaria de Estado da Educação do Paraná. Doutorando no Programa de Pós-Graduação em Educação. Bolsista da Fundação Araucária. ORCID: http://orcid.org/0000-0002-7167-1413. E-mail: epassos3@gmail.com

${ }^{2}$ Pontifícia Universidade Católica do Paraná (PUCPR), Curitiba - PR - Brasil. Professora no Programa de PósGraduação em Educação. Doutorado em Educação (PUCPR). ORCID: http://lattes.cnpq.br/0198429449537597. E-mail: alboni@alboni.com
} 
PALABRAS CLAVE: Imagen fotográfica. Lenguaje visual. Educación. Método.

ABSTRACT: The work of analysis with photographic sources constitutes an impediment in the theoretical and methodological foundations for understanding them as visual language, a source of formation and information. As such, the article deals with the role of photography as a form of visual language composed of ideological signs; it discusses the importance of photographic sources as a collection of documents and presents ways of surpassing the threshold of the instrumental reading of photographic images. The study is justified by the substantive observation of the difficulty of students in reading texts constructed in the visual language, particularly photography. The bibliographical and documentary study, further supported by the dialectic, was based on authors who oppose the reading of photographic images from a positivist perspective. The results made it possible to recognize the nature of photographic images as visual historical sources, which allows the chronological reduction of their production and execution to be overcome.

KEYWORDS: Photographic image. Visual language. Education. Method.

\section{Introdução}

Em relação à perspectiva educacional, a educação brasileira parece não ter incorporado, ainda, nas suas políticas e práticas pedagógicas, os sinais de mutação da modernidade e da cultura imagética, em particular, da cultura fotográfica como fonte de pesquisa.

Tais políticas estendem-se ao processo de formação de professores. Em face à inexistência de uma política pública relativa a essa questão no país, ainda não se criou, no currículo dos cursos superiores de licenciatura, na área de humanas, uma disciplina específica, com fundamentação filosófico-pedagógica, que tenha por objetivo preparar o professor para a alfabetização com a leitura da imagem fotográfica. Na atualidade, como ressalta Kossoy (2001, p. 26), vive-se um dilema: “O mundo tornou-se familiar após o advento da fotografia; o homem passou a ter um conhecimento mais preciso e amplo de outras realidades que lhe eram, até aquele momento, transmitidas unicamente pela tradição escrita, verbal e pictórica”. Ainda, segundo a leitura de Kossoy, o mundo, a partir da alvorada do século XX, se viu, aos poucos, substituído por sua imagem fotográfica. O mundo tornou-se, assim, portátil e ilustrado (KOSSOY, 2001).

Não se pretende, nesse trabalho, traçar uma linha do tempo da educação e das políticas educacionais brasileiras no século XX, tampouco discorrer sobre a ontologia e a gênese histórica da captura da realidade visual pela invenção do processo fotográfico mecânico ou 
tecnológico. Ou seja, parte-se da reflexão de que não se faz história sem a relação dialética com os documentos, independentemente de categorias orais, escritas, sonoras, visuais, entre outras. É nessa perspectiva que a educação para a leitura da mensagem visual, analisada como fonte documental subjetiva, na maioria das vezes, é perpassada pela contradição. Nesse sentido, tal reflexão busca ampliar a leitura crítica e analítica de documentos fotográficos, a fim de superar a sua descrição aparente e factual. Assim, em face à sua natureza complexa, a mensagem fotográfica em si, o que diz e significa, exige um engajamento introduzido por procedimentos teórico-metodológicos da dialética, com a preocupação de compreender a realidade e as experiências sociais (valores, tradições, comportamentos) em determinados tempos históricos, também no sentido de superar a tradição educacional institucionalizada, que ainda centraliza a construção do saber formal nas principais categorias da tradição escrita.

Desse modo, esse artigo pretende discorrer sobre a necessidade de a educação, por meio de políticas públicas em educação, seja na base ou no topo, repensar a importância de se ler com imagens (fotográficas), considerada fonte documental de formação e informação. Entende-se, nesse processo de investigação científica e criação teórica, que a imagem fotográfica se caracteriza como forma de linguagem e, portanto, é matéria. Sendo assim, estáse lidando com algo concreto, que pode ser apreendido e assimilado em forma de conteúdo e conhecimento.

Assim, ao analisar as fontes fotográficas enquanto fonte documental para compreender um determinado período da história, é importante reconhecer esse movimento numa perspectiva crítica, ou seja, no discurso da fotografia, tese e antítese opõem-se, desafiam-se e calam-se em segredos, aguardando a síntese pela abordagem crítica, que de fato revelará a produção do novo. No entanto, o olhar interrogativo e sensível do pesquisador não deve descansar enquanto não aprimorar uma antítese que, por sua força, supere a tese anterior e adote a posição de uma nova tese. A propósito da dialética, “a necessidade deste processo se manifesta a partir de uma mediação, que é condição de possibilidade para que o conceito possa emergir como determinado de tal ou a tal modo: a "Negação"' (OLIVEIRA, 2004, p. 299).

Nesse contexto, é fundamental a função da negação para entender na fotografia os elementos dialéticos: tese e antítese, ou seja, é pela tensão entre os pares dialéticos: proximidade/afastamento, cor/ausência de cor, passado/presente, observador/observado, entre outros, que se leva à reflexão crítica sobre as condições distintas do contexto políticoideológico e tecnológico da sua produção. Nesse sentido, trata-se de uma espécie de dialética do olhar, como reitera Huberman (1998, p. 172): 
[...] uma imagem que critica a imagem - capaz, portanto, de um efeito, de uma eficácia teórica - e, por isso, uma imagem que critica nossas maneiras de vê-la, na medida em que, ao nos olhar, ela nos obriga a olhá-la verdadeiramente. E nos obriga a escrever esse olhar, não para transcrevê-lo, mas para constituí-lo.

Essa exigência de submeter a fotografia à abordagem crítica não isenta o pesquisador do olhar sensível e rigorosamente reflexivo em face à imagem fotográfica. Assim, superar o campo de tenção do factual e aparente da imagem fotográfica significa a compreensão do não explícito, do não dito.

Em cada etapa do surgimento da fotografia no século XIX, a abordagem crítica ocorreu na perspectiva ontológica da sua imagem e em relação ao seu discurso. Nesse período, havia uma preocupação universal entre os críticos da fotografia, no sentido da interferência mecânica na percepção da imagem. Pode-se destacar três correntes de pensamento que se debruçaram em torno dessas questões. No final do século XIX, a primeira delas foi a ideia de mimese, isto é, a fotografia enquanto espelho perfeito do real. Flusser (1985) explica que, na mimese, o interlocutor acredita fielmente na fotografia como extensão dos próprios olhos. No entanto, o próprio Flusser (1985) defende a ideia contrária de mimese, no sentido de que a fotografia teria a função de interpretar e transformar a realidade. Assim, o autor tece a crítica à mimese fotográfica quando argumenta que, por trás do ato fotográfico em si, existe uma série de elementos que perpassam e influenciam o próprio ato de fotografar, como, por exemplo, o aparato técnico a serviço da indústria e do mercado e também a interferência ideológica e a intencionalidade na reprodução do real. No final do século XX, ao rigor da discussão teórica, Philippe Dubois, em "O ato fotográfico" (1998), oferece uma diretriz reflexiva ao propor, no plano teórico, o percurso fotográfico pela via tríade da semiologia em três tempos:

1. A fotografia como espelho do real (o discurso da mimese). O efeito da realidade ligado à imagem fotográfica foi a princípio atribuído à semelhança existente entre a foto e seu referente.

2. A fotografia como transformação do real (o discurso do código e da desconstrução). Logo se manifestou uma reação contra esse ilusionismo do espelho fotográfico. O princípio de realidade foi então designado como pura "impressão", um simples "efeito".

3. A fotografia como traço de um real (o discurso do índice e da referência). Por mais útil e necessário que tenha sido, esse movimento de desconstrução (semiológica) e de denúncia (ideológica) da impressão de realidade deixanos contudo um tanto insatisfeitos (DUBOIS, 1998, p. 26-27, grifo nosso). 
Para o filósofo Philipe Dubois, é indispensável, para que se possa entender o fenômeno da fotografia, partir da ontologia do seu ato fundador, ou seja, para a compreensão do que se busca, deve-se recorrer à sua criação inicial, determinada pela intenção e decisão do que será fotografado, perpassando por todas as suas fases, enquanto linguagem comunicativa que registra, apresenta e representa. Para Dubois (1998), o registro fotográfico deve ser pensado, racionalizado e não se dispara ao acaso, sem antes refletir no sentido de capturar acidentalmente qualquer objeto.

Como se vê nesses autores, observa-se a preocupação de caráter histórico-ontológico com a fotografia na realidade da vida prática, sobretudo, a oposição da leitura fotográfica numa perspectiva positivista, neutra e liberal da realidade.

Não obstante, é precoce atribuir uma causa inicial ou final para esse problema da inoperância de instrumentalizar essas práticas sociais, principalmente quando ocorre uma cultura do pensamento único, do senso comum, de que imagem (fotográfica) não deve ser lida. Ou, no mais das vezes, a ideia distorcida de que ler a imagem é simplesmente fácil.

Quando se reflete sobre o trabalho com fontes fotográficas, pressupõe-se que tal prática não se dá exclusivamente no plano cartesiano, mas, sim, também no dialético. Desse modo, a imagem fotográfica representa uma forma de linguagem extremamente dinâmica e polissêmica, que exige uma disposição complexa por parte do receptor, a fim de resolver a sua interpretação.

\section{A leitura da imagem fotográfica: justificativas e finalidades}

Numa perspectiva pouco reflexiva, a fotografia ainda não superou o seu papel utilitário no nível do entretenimento, principalmente, com uma preocupação especial epistemológica com o uso da imagem retratada. Ou seja, a fotografia não se resume apenas no automatismo do clique, sem a mediação entre o fotógrafo e a coisa retratada, isto é, a fotografia não existe sem o seu objeto. Para Rouillé (2009, p. 30), “[...] $]^{3}$ o menor enquadramento é já um posicionamento ideológico sobre as coisas". Para o autor, não existe neutralidade no ato fotográfico, mas, sim, haverá uma mediação entre a fotografia e o objeto retratado.

Numa perspectiva materialista histórica e dialética, Ciavatta (2002, p. 16), diz:

${ }^{3}$ Entrevista com André Rouillé, com o apoio da Coordenação de Aperfeiçoamento de Pessoal de Nível Superior (CAPES), Université Paris 8, 2009. Disponível em: http://www.studium.iar.unicamp.br/31//. Acesso em: 3 jun. 2018. 
O primeiro olhar é sobre o próprio objeto fotográfico, o artefato, o simulacro, a imagem fotográfica. A fotografia como recriação da realidade, como simulacro que é e não é, ao mesmo tempo, o objeto real, a fotografia no que mostra e no que dissimula, como conhecimento dissociado da experiência que redefine a própria realidade.

Essa construção dos sentidos, da qual trata Ciavatta, ocorre de forma dialética, isto é, o sentido que o leitor busca construir não está pronto e acabado na fotografia e nem nele mesmo, mas é por meio da incorporação das pistas que a imagem fornece (presença/ausência) ao leitor, associada ao seu conhecimento de mundo ou epistemológico, que se chegará à superação e ao sentido de identidade esperado. Dessa forma, a leitura da imagem fotográfica acaba exigindo do leitor um pensar dialeticamente (pelo que são/pelo que não são).

Ler imagens (fotográficas) representa um desafio contemporâneo até mesmo para entendermos as complexas redes de relações políticas que fazem parte do nosso cotidiano. Grandes empresas de comunicação usam as imagens (cinematográficas, televisivas, infográficas, fotográficas) como mecanismos de poder e manipulação da sociedade. Isso ocorre por meio do processo de produção de bens, serviços e consumo. Nesse sentido, ao pensar a imagem fotográfica como mercadoria, com bons fins lucrativos e forte capacidade cognitiva de controle social, somos levados a questionar a versão legislativa do governo, do gestor público e do capital como sendo ideologizadas, ou seja, todos apresentam ações, fazendo-nos sempre crer que estão a considerar o interesse da sociedade e ocultando o interesse político e comercial implícito.

No sentido da afirmação acima, educar para a leitura da imagem é propiciar ao aluno a leitura do mundo que o cerca: publicidades, fotografias, esculturas, propagandas de natureza política, imagens da mídia, entre outras. Portanto, o estudo da imagem representa uma necessidade imperiosa na educação brasileira.

Pode-se dizer que vivemos hoje na sociedade do espetáculo da imagem, como alerta Gui Debord. Por se tratar de algo comum entre nós, como se vê, não a vemos. Segundo Merleau-Ponty, "Hoje muito se observa, mas pouco se vê. A visão não é nada sem um certo olhar. É necessário olhar para ver" (MERLEAU-PONTY, 1971, p. 229). Ou seja, as imagens se entrecruzam em constante devir, o que nos obriga a delinear a nossa percepção para ler imagem entre imagens, uma mistura entre ficção e realidade. Nas palavras elucidativas de Eco (1976, p. 353), “Uma civilização democrática só se salvará se fizer da linguagem da imagem uma provocação à reflexão crítica, não um convite à hipnose". 
A imagem fotográfica coopera para o desenvolvimento do olhar, isto é, em um primeiro momento, quando passamos os olhos sobre a sua superfície, podemos nos questionar no sentido de desacreditar sobre a nossa intenção de ler a imagem fotográfica, pois está tudo muito legível, semelhante e aparente, portanto, ler o quê? Outra questão que nos incomoda na leitura da imagem fotográfica é pensar no sentido da intencionalidade do autor (fotógrafo), ou seja, “[...] onde ele quis chegar com tudo isso?”. A outra questão é pensar a fotografia como processo da criação artística, que não ocorre somente por meio da atividade metódica e cartesiana, mas também do emocional e afetivo. Desse modo, não caberia à análise do invisível?

Assim, parece que o poder da imagem fotográfica de nos cegar é maior do que a reflexão crítica do homem sobre ela. Isto é, quando olhamos para a fotografia, ela também nos olha e antes que possamos decifrá-la criticamente, ela nos hipnotiza e somos prazerosamente levados a contemplá-la sem esforço e sem hesitação. Ainda, nessa perspectiva, Soulages (2010, p. 129, grifo do autor), diz:

Dessa maneira a fotografia designa a propriedade abstrata que faz a singularidade do fato fotográfico - e esse fato remete tanto ao sem-arte quanto à arte. Mas o que é ainda mais interessante de se observar, a partir da propriedade de Todorov, é a possibilidade de se preocupar, graças ao conceito de fotograficidade, não só com a fotografia real, mas também com a fotografia possível, e até com as potencialidades fotográficas; ora, justamente uma das características da fotograficidade é o inacabável, ou seja, o fato de ter potencialidades sempre manifestáveis ao infinito: a fotografia é, portanto, a arte do possível, tomada em seu sentido próprio.

Levando em conta o que nos diz Soulages sobre as potencialidades inacabáveis no trato com a fotografia em si ou especificamente com o seu negativo, acredita-se que uma análise ontológica do "ser" fotografia não deve ser feita por si mesma, mas a serviço de um projeto que perpasse a perspectiva do universal ao particular, o que inclui a arte do possível.

\section{Fotografia e educação: o trabalho com fontes fotográficas na Educação Básica}

Um caminho possível para se trabalhar com fontes fotográficas, na educação básica, passa pelo entendimento da necessidade de se apresentar uma concepção dialógica da linguagem e da comunicação que valorize o aspecto da fotografia como fonte histórica na educação básica para o conhecimento da realidade. Como assinala Kossoy (2001, p. 31), “[...] com a Revolução documental das últimas décadas e, com o alargamento do conceito que o termo documento passou a ter, a fotografia começou a ser tratada de forma diferenciada". 
Nessa perspectiva, a ideia de trabalhar com fontes fotográficas, no sentido de entender os fenômenos da educação a partir do seu processo de produção, leva-nos em especial a refletir sobre a própria prática social e cultural, que exige de nós uma reflexão epistemológica e ontológica como categoria do ser social no nível concreto da realidade objetiva e no nível gnosiológico da abstração conceitual.

Historicamente, tem-se dado pouca importância sobre as formas de aplicação do uso da imagem na organização curricular da Educação Básica. Tendo em vista o descaso na efetivação da legislação das políticas públicas educacionais relativas à cultura visual, Mauad (2008, p. 42), afirma:

A fotografia deve ser considerada como produto cultural, fruto de trabalho social de produção sígnica. Neste sentido, toda a produção da mensagem fotográfica está associada aos meios técnicos de produção cultural. Dentro desta perspectiva, a fotografia pode, por um lado, contribuir para a veiculação de novos comportamentos e representações da classe que possui o controle de tais meios, e por outro, atuar como eficiente meio de controle social, através da educação do olhar.

Reiterando Mauad, cabe lembrar a presença de grupos dominantes do mercado da informação visual, por exemplo: o mercado livreiro de didáticos, que estão intrinsecamente ligados aos aspectos capitalistas atuais (educação, mídias digitais, hipermídia, arte eletrônica), principalmente, no que diz respeito à transmissão ideológica e às relações de poder, a fim de conduzir o educando a uma visão de mundo prefixada, que impede o desenvolvimento do espírito crítico. Enquanto isso, a educação básica ainda padece do entendimento de que a imagem fotográfica não é a realidade em si, mas uma representação da realidade. Nesse sentido, Schlichta (2009, p. 58) afirma:

O que se vê, muitas vezes, nas imagens são visões açucaradas do amor, benefícios da pobreza, o sacrifício da submissão, as divisões de papéis sociais etc. Porém, é preciso cuidado com o viés de que é próprio da imagem mostrar algo, pois nela nada aparece em tamanho natural, nada é visível como tal. O que é visível é a consciência ou a compreensão de si ou da realidade humano-social, isto é, a sua ideologia. Mas, a ideologia não está "colada" no conteúdo das imagens, está na sua representação.

Em face a isso, cabe esclarecer que a não incorporação da organização curricular pelo mundo das imagens, em particular a imagem fotográfica, ultrapassa a realidade do descompromisso político e a competência técnica acadêmica, para alfabetizar o professor para a leitura do visual. Nessa perspectiva, cabe lembrar que, a serviço do capital, existe uma 
grande força produtiva, denominada indústria cultural ${ }^{4}$, que trabalha com uma visão tendenciosa e normativa, a qual reduz a imagem fotográfica simplesmente à forma de comunicação e mercadoria, distanciando-a da sua realidade social e histórica.

\section{Procedimentos metodológicos como acesso de aproximação da realidade fotográfica}

O método implica lançar-se ao desafio da ação investigativa na busca dos regimes de verdade, ou seja, como pregava Foucault (2010), não há verdade dada, há regimes de verdade. Cabe ao pesquisador teorizar a prática, a fim de aproximar-se da realidade material ou imaterial do problema, para superá-lo e construir o novo, o que requer do observador certo deslumbramento pelo mundo da ciência e da filosofia.

Para o cientista, o método representa o sustentáculo para sair do já posto. Isto é, um caminho para avançar no trabalho científico e construir o conhecimento racional, sistemático e verificável da realidade. As revoluções no campo das ciências naturais e sociais mostramnos a importância do método como um caminho que pode nos levar a novas direções, com o objetivo de aproximarmo-nos da realidade do objeto ou problema de investigação.

No caso da fotografia, a dificuldade de uma análise estrutural ou filosófica é paradoxal, isto é, vê-se pouco consenso no debate teórico entre pesquisadores e estudiosos em relação à exatidão da ontologia do "ser" imposto pela fotografia, até porque quando se pensa no regime de verdade da fotografia, há de se pensar as diferentes posições do fotógrafo em face à experiência fotográfica, principalmente, porque a verdade da fotografia digital, pensando no computador, é diferente da verdade e da incerteza da fotografia analógica. Embora seja fato de que a fotografia é criação do homem moderno e pós-moderno, a imagem de Proteu é oportuna para pensar à fotografia.

Parafraseando a imagem de Proteu na "Odisseia", deus marinho com capacidade de prever o futuro e mudar de forma de acordo com as necessidades e circunstâncias dominantes: fogo, vegetal, animal, água... a imagem fotográfica também pode ser proteica, principalmente, porque cada leitor pode reivindicar a sua verdade na mutação contínua do seu ser, ou seja, em pleno século XXI, a imagem fotográfica ainda pode ser, paradoxalmente, tudo e seu contrário - signo e não signo, humana e inumana, presencial e consciencial, artificial e natural, índice e ícone, significado e significante, cosmológica e antropológica, destinatário e referente.

${ }^{4} \mathrm{O}$ termo indústria cultural (em alemão Kulturindustrie) foi criado pelos filósofos e sociólogos alemães Theodor Adorno (1903-1969) e Max Horkheimer (1895-1973), a fim de designar a situação da arte na sociedade capitalista industrial. SILVA, D. R. Adorno e a indústria cultural. Disponível em: http://www.urutagua.uem.br/04fil_silva.htm. Acesso em: 03 jun. 2018. 
Enfim, como preconizava Raul Seixas, sem o menor exagero, a fotografia é uma metamorfose ambulante, de semiose e classificação ilimitada sobre tudo.

Essas incertezas semióticas levam-nos a refletir sobre a versatilidade da imagem fotográfica, no sentido camaleônico que lhe atribui Proteu. Inclusive, a imagem fotográfica como linguagem dialógica e signo ideológico.

Para melhor inserir no texto, Chauí (1983, p. 81) trata sobre a legitimidade teórica quanto ao uso da prática no método de pesquisa científica:

Que significa dizer que a relação entre teoria e prática é dialética e não ideológica (como aquela relação que mostramos ser feita pelos positivistas)? A relação entre teoria e prática é uma relação simultânea e recíproca por meio da qual a teoria nega a prática enquanto prática imediata, isto é, nega a prática como um fato dado para revelá-la em suas mediações e como práxis social, ou seja, como atividade socialmente produzida e produtora da existência social.

Nessa relação dialética entre teoria e prática, prevalece o princípio da contradição. A existência da teoria acaba determinando a existência da prática e vice-versa. No entanto, para que ambas existam, é necessário que sejam diferentes, isto é, opostas. Assim, procura-se antecipar algumas questões de ordem metodológica, que confirmam que estamos diante de um objeto de análise complexo. Frente a essa observação, há duas possibilidades reais de aproximação do problema da leitura compreensiva e crítica.

A primeira trata dos procedimentos metodológicos da filosofia da linguagem, por meio da obra "Marxismo e filosofia da linguagem", de Bakhtin, com o propósito, segundo Bakhtin (1997, p. 38) de:

[...] fazer com que o método sociológico marxista dê conta de todas as profundidades e de todas as sutilezas das estruturas ideológicas "imanentes" consiste em partir da filosofia da linguagem concebida como filosofia do signo ideológico.

Ou seja, a imagem fotográfica diferencia-se das outras formas de imagem pela sua natureza de continuidade, o que se opõe, no exemplo, à característica discreta e descontínua da linguagem verbal escrita e falada.

Tem-se, na filosofia da linguagem uma ferramenta eficaz e que pode ser uma grande aliada do Materialismo Histórico e da dialética no processo da compreensão do problema. Pode-se dizer que a semiótica da comunicação desenvolvida por Bakhtin, por meio da concepção dialógica da linguagem e da comunicação, isto é, o diálogo entre interlocutores e o 
diálogo entre discursos representa uma das poucas teorias capazes de superar as categorias funcionais da imagem fotográfica.

Para trabalhar com o Materialismo Histórico e a dialética não basta simplesmente descrevê-los conceitualmente. É necessário avançar além da mera reprodução teórica. É necessária uma reflexão filosófica a partir de uma perspectiva ontológica da obra de Marx (1985). Segundo Gadotti (1990, p. 30, grifo nosso), sobre o método dialético:

Essas leis ou princípios da dialética não surgiram a priori; São frutos de um lento amadurecimento e do próprio desenvolvimento das ciências modernas. Em Marx surgem após uma análise exaustiva do modo de produção capitalista, consequência de uma análise científica como ele próprio afirma. Só depois de concluído o trabalho é que Marx pôde evidenciar essas categorias e mostrar o caminho (método) que ele percorreu, pôde anunciar, manifestar, o seu método natural, concreto, não abstrato.

Assim, é fundamental compreender o desenvolvimento do método dialético, a fim de tentar captar o movimento das contradições reais no que diz respeito às determinações objetivas possuídas pela própria fotografia, principalmente, no seu estado material da significação e no contexto de sua produção enquanto linguagem de caráter social e ideológico.

\section{Categorias do método e da análise}

Dentre os estudiosos do debate teórico sobre a imagem (fotográfica), o apresentado por Martine Joly parece-nos o mais importante para o artigo. Entende-se, portanto, que para chegar a uma possibilidade de compreensão do paradoxo fotográfico, o caminho é pela perspectiva universal de imagem.

Nas palavras de Joly (2005, p. 38), as imagens podem ser compreendidas conceitualmente como:

[...] uma imagem é antes de mais nada, algo que se assemelha a outra coisa. Mas quando não se trata de imagem concreta, mas mental, unicamente o critério de semelhança a define: ora se parece com a visão das coisas (o sonho, a fantasia), ora se constrói a partir de um paralelismo qualitativo (metáfora verbal, imagem de si, imagem de marca). A primeira consequência dessa observação é constatar que esse denominador comum da analogia, ou da semelhança, coloca de imediato a imagem na categoria das representações. Se ela parece é porque ela não é a própria coisa: sua função é, portanto, evocar, querer dizer outra coisa que não ela própria, utilizando o processo da semelhança.

A explanação sobre a imagem caracteriza-se como representação analógica e é percebida como signo. Sendo assim, terá um sentido, isto é, ela é linguagem com potencial de 
leitura tanto pelo seu aspecto significante como pelo significado. Essa confirmação garantenos trabalhar com o objeto fotografia com essa perspectiva. Nesse sentido, Joly (2005, p. 40) afirma:

$\mathrm{Na}$ maioria das vezes, as imagens registradas assemelham-se ao que representam. A fotografia, o vídeo, o filme, são considerados imagens perfeitamente semelhantes, ícones puros, ainda mais confiáveis porque são registros feitos a partir de ondas emitidas pelas próprias coisas.

Para Joly (2005, p. 40), “[...] a fotografia é um ícone puro”. Sendo ícone, pode ser polissêmica e ideológica. Nessa mesma linha teórica e permeando as regras metodológicas em “Marxismo e filosofia da linguagem”, Bakhtin e Volóchinov (1997, p. 44) afirmam:

1. Não separar a ideologia da realidade material do signo (colocando-a no campo da "consciência" ou em qualquer outra esfera fugidia e indefinível).

2. Não dissociar o signo das formas concretas da comunicação social (entendendo-se que o signo faz parte de um sistema de comunicação organizada e que não tem existência fora deste sistema, a não ser como objeto físico).

3. Não dissociar a comunicação e suas formas de sua base material (infraestrutura).

O ponto de partida dessa leitura trata da aceitação incondicional de que linguagem verbal e imagem fotográfica não se opõem totalmente em sistemas únicos individuais, com códigos específicos que expliquem cada um por completo. Embora sejam códigos distintos, é fato que para falar sobre a imagem fotográfica é raro usar outra imagem.

Para sintetizar essa questão, a abordagem da imagem na sociedade contemporânea está ancorada em duas vertentes principais. Em primeiro lugar, a imagem está posta no sentido de signo linguístico e filosófico, que determina a sua natureza arbitrária, referencial e imitativa. Uma segunda posição transporta a imagem para a sua natureza mais específica do aspecto visual: cores, traços, distância, sombra, profundidade e textura.

De resto, o que nos interessa na sequência do presente texto é sugerir uma possibilidade de leitura para a imagem fotográfica como fonte documental, principalmente, sem perder seu aspecto icônico, com diagramas, metáforas, índices e símbolos.

A possibilidade de leitura da imagem fotográfica proposta volta-se à totalidade da imagem enquanto linguagem visual, discurso mediação e movimento de construção histórica. Sobre isso, afirma Souza (2001, p. 4):

O texto visual, em seu todo, é tido como um conjunto de estruturas produtivas, cujo modelo pressupõe: expressão visual; elementos de expressão (figuras geométricas e ângulos de câmera); níveis sintagmáticos 
(figuras iconográficas, tipologia da montagem, relação campo/contracampo, etc.); blocos sintagmáticos com função textual (montagem; tipos de enquadre; narrativa/cronologia temporal; diferentes pontos de vista); níveis intertextuais; tópico; gênero e tipologia de gêneros.

Em face ao caráter heterogêneo da imagem fotográfica, exigir-se-á do leitor um afastamento da mera descrição técnico-formal. Isso pode impedir, segundo Souza (2001, p. 5), "que se perca a materialidade significativa da imagem na sua dimensão discursiva". Considera o autor que o estudo das imagens não pode perder de vista os diferentes aspectos e contextos sociais e históricos em que foram produzidas.

Contudo, uma das questões complexas no estudo da imagem fotográfica é revelar, por meio da linguagem verbal, a sua matéria visual. Isto é, a materialidade da imagem não pertence à natureza do código verbal elaborado, mas, sim, à natureza da forma visual. Assim, o que se pode fazer com o verbal é descrever, falar e ler ou interpretar a imagem. Dessa forma, assevera-se o seu caráter de linguagem.

\section{A análise do discurso na imagem fotográfica}

$\mathrm{Na}$ leitura da imagem fotográfica, acaba-se construindo outras imagens, que segundo Souza (2001, p. 6), “[...] não é da ordem da visibilidade, mas da ordem do simbólico e do ideológico e do discurso". Nesse processo de tomar a imagem fotográfica como objeto empírico da análise do discurso, faz-se necessário projetar nosso olhar sobre as várias instâncias que contribuem para a sua materialidade, o histórico, o social e o cultural.

Assim, nesse movimento reflexivo no processo da leitura, faz-se necessário identificar os enunciados (ideológicos, simbólicos, icônicos, entre outros), presentes na parte material da imagem, que pertencem a um discurso, e separá-los dos que não pertencem.

Vale ressaltar que construir um sentido na imagem, como discurso, exige, do pesquisador, professor e aluno, problematizar a sua aparência visual inicial e superar, ultrapassar a descrição dessa aparência imediata, atribuindo-lhe uma significação do ponto de vista social e ideológico.

$\mathrm{Na}$ análise do discurso do texto verbal, faz-se necessário reconhecer as muitas vozes que falam no texto e observar de que perspectiva ideológica e social esses enunciados falam. Ducrot (1987) chamou esse emaranhado de vozes que falam no texto de polifonia, ou seja, um enunciado é constituído na maioria das vezes pelo enunciado do discurso do outro. Desse modo, cabe ao analista do discurso identificar, no texto, as marcas de heterogeneidade e as 
circunstâncias da enunciação. Em relação à linguagem visual, Souza (2001, p. 12) observa o seguinte:

O texto de imagens também tem na sua constituição marcas de heterogeneidade, como o implícito, o silêncio, a ironia. Marcas, porém, que não podem ser pensadas como vozes, porque analisar o não verbal pelas categorias de análise do verbal implicaria na redução de um ao outro. Nesse caso, por associação ao conceito de polifonia, formulamos o conceito de policromia buscando analisar a imagem com mais pertinência. $\mathrm{O}$ jogo de formas, cores, imagens, luz, sombra, etc., nos remete à semelhança das vozes no texto. Essa correlação se faz através de operadores discursivos não verbais: a cor, o detalhe, o ângulo da câmara, um elemento da paisagem, luz e sombra etc., os quais não só trabalham a textualidade da imagem, como instauram a produção de outros textos, todos não verbais.

No âmbito da leitura da imagem, o conceito de policromia "[...] como rede de elementos visuais, implícitos ou silenciados" (SOUZA, 2008, p. 12), sem dúvida, representa uma das ferramentas teóricas fundamentais da práxis do autor e do leitor para a leitura da imagem fotográfica.

A presença desse saber, na análise do discurso, consiste na tentativa de responder a algumas questões em relação à imagem fotográfica: quem fala na imagem? A quem se fala? O que significa o que se fala? Tendo em vista a questão específica, como se deve ler essa imagem? O que foi registrado? Sob que ângulo? Por quem? Por quê? Onde? Quando? Imprescindivelmente, deve-se levar em consideração que o caráter polifônico da linguagem (escrita e fala) complementa-se com os aspectos policrônicos (a imagem) na construção de sentidos. Embora cada uma dessas linguagens (verbal e não verbal) apresente, na sua materialidade ontológica, características e categorias individuais e autônomas, elas complementam-se entre si.

Em relação à compreensão no discurso, Bakhtin e Volóchinov (1997, p. 93) afirmam o seguinte:

Mas o locutor também deve levar em consideração o ponto de vista do receptor. Seria aqui que a norma linguística entraria em jogo? Não, também não é exatamente assim. É impossível reduzir-se o ato de descodificação ao reconhecimento de uma forma linguística utilizada pelo locutor como forma familiar, conhecida - modo como reconhecemos, por exemplo, um sinal ao qual não estamos suficientemente habituados ou uma forma de uma língua que conhecemos mal. Não; o essencial na tarefa de descodificação (compreensão) não consiste em reconhecer a forma utilizada, mas compreendê-la num contexto concreto preciso, compreender sua significação numa enunciação particular. 
Nesse fragmento, Bakhtin e Volóchinov reiteram a ideia de que a construção do sentido que se busca no texto (verbal ou não verbal) primeiramente está ancorada no contexto particular, privilegiado, entre locutor e receptor. No entanto, não se restringe a ele, pois se deve levar em consideração fatores de historicidade, ordem social (norma) e contradição.

Como consideram Bakhtin e Volóchinov, o signo é descodificado, isto é, compreendido pelo seu caráter heterogêneo ideológico, ele é forma e conteúdo que conduz o sentido para a materialização dos processos discursivos. Nessa perspectiva dialética, o signo é constituído do sinal, no entanto, ele em si é neutro e de caráter estritamente instrumental.

Numa perspectiva bakhtiniana, as formações discursivas ocorrem dentro de uma realidade material e ideológica inseparáveis. Como afirma Orlandi (1995, p. 61):

É a formação discursiva que determina o que pode e deve ser dito, a partir de uma posição dada numa conjuntura dada. Isso significa que as palavras, expressões etc. recebam seu sentido da formação discursiva na qual são produzidas. Dito de forma mais direta, a formação discursiva é lugar da construção do sentido (sua matriz, por assim dizer).

A partir desses pressupostos, podemos dizer que o choque ideológico está centrado na base da formação discursiva produzida pelos interlocutores. Entretanto, o sentido do texto, seja ele verbal (uma palavra ou expressão) ou não verbal (uma imagem fotográfica, um filme, uma propaganda, etc.), não existe em si mesmo. Desse modo, a compreensão que se busca construir no texto e no seu discurso, para superar a interpretação inicial e imediata, perpassa pelo reconhecimento e a desconstrução das marcas ideológicas presentes no texto, o que exigirá do leitor fazê-lo por meio da crítica e da problematização do caráter ideológico da linguagem.

A consideração que Bakhtin faz sobre a neutralidade da palavra está na base do método sociológico marxista. Para Bakhtin e Volóchinov (1997, p. 36, grifo nosso):

A palavra é o fenômeno ideológico por excelência, ela acompanha e comenta todo ato ideológico, toda criação ideológica, seja ela qual for. Mas a palavra não é somente o signo mais puro, mais indicativo; é também um signo neutro. Cada um dos demais sistemas de signos é específico de algum campo particular da criação ideológica.

Em suma, a palavra, na sua essência individual, é neutra. Ela só ganha sentido numa situação discursiva, sobretudo, levando-se em consideração a posição social, política, ideológica e religiosa de onde o sujeito fala. Isso implica que, em relação ao nosso objeto de análise, as imagens fotográficas, como signos não verbais, segundo Bakhtin e Volóchinov (1997, p. 38), "banham-se no discurso e não podem ser totalmente isoladas nem totalmente 
separadas dele”. Desse modo, a imagem não vale mil palavras, ou qualquer outro número. Complementa-se que "nem sequer existe um substituto verbal realmente adequado para o mais simples gesto humano" (BAKHTIN; VOLÓCHINOV, 1997, p. 38).

Tais considerações, no sentido de ler a fotografia, levam-nos a compreender a importância de pensá-la inserida numa realidade material e como signo ideológico. Bakhtin determina que nenhum signo ideológico deve ser substituído por palavras, no entanto, para falar da imagem, é necessário usá-la.

Sobre o tópico, o sujeito e a significação, com as considerações teóricas dos outros tópicos (atividade discursiva, interpretação do discurso, o sentido no discurso, a formação discursiva, polifonia e policromia, entre outros), que avançamos para a análise do discurso da imagem fotográfica.

Em relação ao sujeito e a significação, Orlandi (1995) parte da concepção e da discussão a respeito do inteligível, do interpretável e do compreensível na leitura.

A leitura da fotografia pode ser mais produtiva levando-se em conta a busca pela sua compreensibilidade em relação a sua inteligibilidade e a sua interpretabilidade. Cada uma dessas três categorias de leituras (o inteligível, o interpretável e o compreensível) caracterizam-se entre si, "pelos seus objetivos internos e externos nos processos de produção da leitura" (ORLANDI, 1995, p. 58).

O objetivo interno "é aprender, no domínio do discurso, o funcionamento da compreensão: o que é, quais são seus mecanismos, o que representa em termos de discurso etc.” (ORLANDI, 1995, p. 58). Esse recurso usado advém do princípio dialógico criado por Mikhail Bakhtin.

Por outro lado, os objetivos externos são os enfrentamentos, as dificuldades, os problemas e os desafios protagonizados pelos falantes e ouvintes na produção do discurso e como chave para a ampliação da produção da leitura, sobretudo no sentido de possibilitar ao leitor (aluno) uma capacidade de apreensão das contradições por meio de um olhar mais sensível da realidade. Assim, Orlandi (1995, p. 73) apresenta a seguinte distinção entre “inteligível, interpretável e compreensível":

O inteligível: ao que se atribui sentido atomizadamente (codificação); O interpretável: ao que se atribui sentido, levando-se em conta o contexto linguístico (coesão);

O compreensível: é a atribuição de sentidos, considerando o processo de significação no contexto de situação, colocando-se em relação enunciado/enunciação. 
Desse ponto de vista, a análise do discurso da imagem fotográfica proposta nesse artigo leva-nos a considerar a linguagem visual como a exterioridade. Isto é, em que deriva as condições de produção do discurso: o autor da fotografia, o leitor, o contexto e o contexto sócio-histórico.

Assim, consideramos, na leitura da imagem fotográfica, partir da coisa em si, daquilo que foi materialmente necessário para a existência da fotografia, no entanto, o mais importante não são os objetos retratados como estão, mas, sim, os mesmos objetos modificados, traduzidos e interpretados por um olhar. Isto é, assimilamos, absorvemos e reproduzimos o reflexo da imagem, porém, com uma nova impressão.

Enfim, parece que esse processo de construção teórica possibilitou os instrumentos necessários para alicerçar e buscar as determinações que possibilitem o trabalho da análise do discurso na imagem fotográfica.

Observa-se nos questionamentos instigantes dos autores com os quais se dialogou que a educação representa a força motriz na constituição do existir do ser humano. Portanto, pensar a formação para a cultura da imagem fotográfica é pensar o homem na sua totalidade, nas várias dimensões que assume nas suas relações sociais. Sobre essa questão, Edgar Morin, em entrevista ao programa "Roda Viva", de 18/12/2000, fala sobre sua obra "Os sete saberes necessários à educação do futuro":

[...] o homo sapiens só... O homem da inteligência não é só o homo sapiens (homem sábio), indissoluvelmente. Ele é o homo demens (homem louco), o homo faber, que trabalha; que brinca (homo ludens); o homo economicus (homem econômico), o homo poeticus (homem poético); o homo mitológico, empiricus, imaginarius, consumans, prosaicus etc. (MORIN, 2000, p. 2).

Assim, conclui-se que compreender a ontologia da imagem fotográfica passa, necessariamente, pela compreensão integral e omnilateral do ser humano.

No contexto da explanação teórica e efetivamente sintonizado com a teoria da análise do discurso e do materialismo dialético, apresenta-se a leitura de duas imagens fotográficas, que de certa forma estão carregadas de sentido ideológico e merecem uma leitura reflexiva em face ao seu caráter contraditório.

A diferença temporal da produção da Figura 1, de autoria do jornalista Roitberg (2008), em relação à Figura 2, de Augusto Flávio de Barros (1897), é de 111 anos. Independentemente da barreira de tempo e espaço entre as produções, observa-se, em ambos,

${ }^{5}$ Disponível em:

http://www.rodaviva.fapesp.br/materia/207/roda_viva/sobre_o_projeto.htmhttp://www.rodaviva.fapesp.br/materi a/207/roda_viva/sobre_o_projeto.htm. Acesso em: 03 jun. 2018. 
os contextos de produção (histórico, cultural, ideológico, religioso, etc.), um misto de razão, emoção e sensibilidade, no movimento permanente de recriação da realidade.

Figura 1 - Miséria

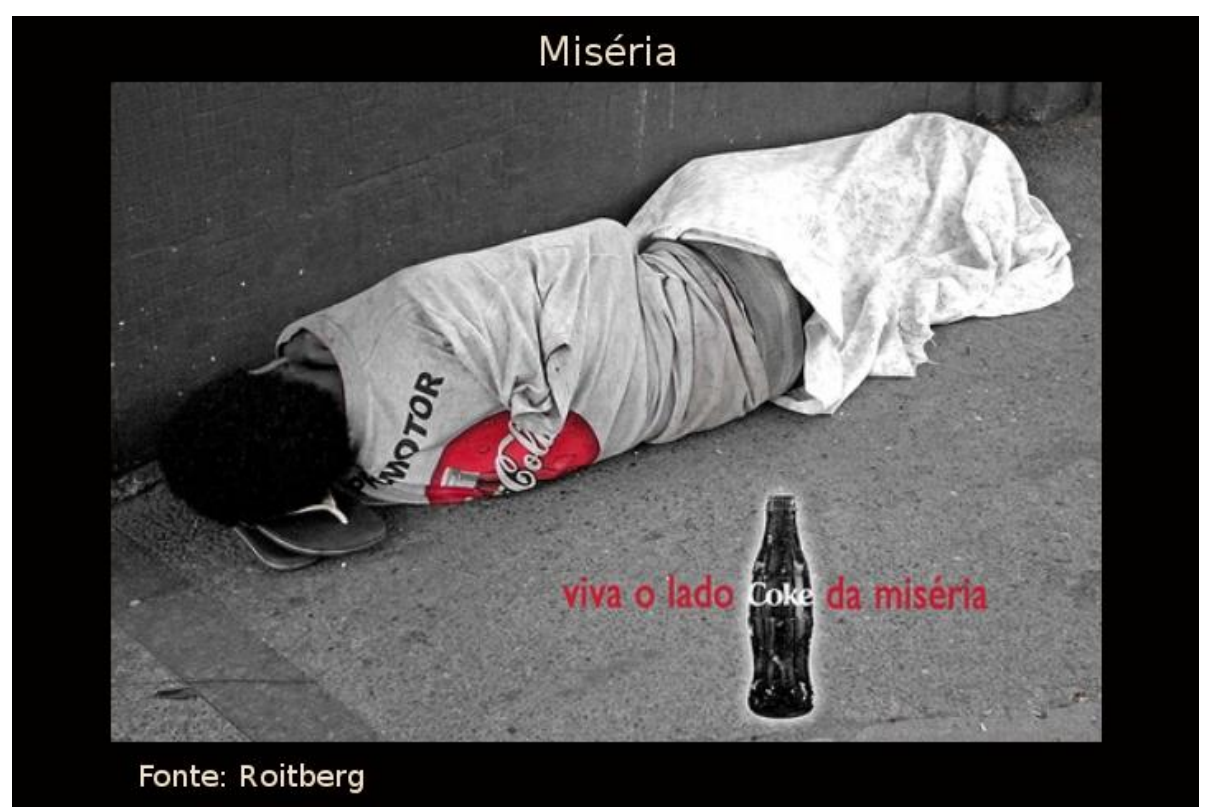

Fonte: Torralvo e Minchillo (2010, p. 125)

A fotografia do jovem deitado no chão, coberto por uma camisa da Coca-Cola, serviu de forma instrumental numa questão gramatical orações adjetivas restritivas, no livro de língua portuguesa "Linguagem em movimento" (2010), ou seja, um recorte descontextualizado da origem da fonte em si, adaptado para criar o exercício no livro didático. Ao pesquisar a procedência e a trajetória da imagem fotográfica, a fim de se alcançar o sentido maior, chegou-se à informação de que a Figura 1 é de autoria do jornalista José Roitberg $^{6}$ (2008), quando passava pela Rua do Catete, no centro do Rio de Janeiro. A imagem postada no site $^{7}$ vem acompanhada dos seguintes enunciados: "Brazilian version - fake ad. Foto de rua verdadeira, Coca-Cola Sempre... Tenha uma Câmera". Nesse contexto, o caso singular de o jornalista ter feito as seguintes afirmações na postagem da foto na internet revela-nos o seu ímpeto ativo e sensível, no sentido de que "[...] não se fotografa qualquer coisa, a escolha do que será fotografado segue alguns protocolos que são perpassados pelas experiências sociais compartilhadas [...]" (MAUAD, 2008, p. 19), ou seja, saber o circuito

${ }^{6}$ Jornalista, professor sobre o Holocausto, formado no Yad Vashem e pesquisador sobre a história dos judeus e do Rio de Janeiro. É um dos maiores documentadores da história da publicidade da Coca-Cola e do Natal, com milhares de anúncios publicitários organizados e disponíveis na internet, trabalho também iniciado em 1995. Estudantes e professores de publicidade e marketing. Disponível em: http://roitblog.blogspot.com.br/2008/. Acesso em: 20 maio 2019.

${ }^{7}$ Disponível em: http://roitblog.blogspot.com.br/2008/. Acesso em: 20 maio 2019. 
social no qual o fotógrafo está inserido profissionalmente ajuda a entender a valorização dada àquela realidade em questão, isto é, a escolha não foi feita de forma aleatória: o menino vestia uma camisa da Coca-Cola!

A princípio, tal decisão representa valores ideológicos e culturais do grupo social ao qual o jornalista pertence, isto é, trata-se de um dos maiores documentadores da história da publicidade da Coca-Cola e do Natal. Nesse sentido, esses indicadores revelam-nos uma preocupação estética particular desse fotógrafo. No entanto, o que nos interessa é compreender e superar essa primeira leitura, o que essa imagem veicula e o que ela oculta, ou seja, como diz Boris Kossoy (2001, p. 95), "ver, descrever e constatar não é o suficiente".

A fotografia retrata um menino negro, deitado na calçada, com a camisa da Coca-Cola, tendo como travesseiro um par de chinelos. Por meio de um arranjo técnico, o autor dessa fotografia parodia o slogan positivo dessa marca, "viva o lado bom da vida", por "viva o lado coke da miséria”. Não há informações sobre quem é o menino e quais os principais motivos que o levaram a morar na rua. No entanto, o contexto histórico em que a imagem foi produzida retrata a miséria urbana, cuja impressão revela o descaso das políticas públicas com o problema dos menores abandonados.

O slogan "viva o lado bom da vida", com seu amplo potencial retórico de persuasão, parodia a objetividade positivista do senso comum "viva o lado bom da vida". Desse modo, a aparente inocência do slogan da Coca-Cola constrói uma representação da realidade baseada na alegria, na felicidade, no bem-estar e no prazer. Ou seja, ao ver e ouvir o anúncio dessa marca com imagens repletas de efeitos especiais do universo fantástico (borboletas coloridas, jovens dançando e sorrindo, atletas na linha de chegada, entre outras), tudo isso acompanhado de uma música contagiante, leva o telespectador, por alguns instantes, a viver o mundo positivo da vida, sem violência, sem estresse, sem os problemas do dia a dia, ou seja, a ausência da visão crítica como único reflexo da realidade e com testemunho neutro.

Portanto, a fotografia do jornalista José Roitberg, associada ao seu slogan "viva o lado coke da miséria”, contrapõe a ideia positivista veiculada no anúncio da Coca-Cola e desvela o caráter contraditório da representação de um mundo ideal. Nesse sentido, o jornalista mostra, na fotografia, que por trás desses grupos dominantes do poder econômico, que estimulam o consumo, as desigualdades e a hegemonização da riqueza na sociedade, há a realidade humano-social com todas as misérias: pobreza, infelicidade, morte, violência, entre outras. 
Figura 2 - Rendição dos conselheiristas

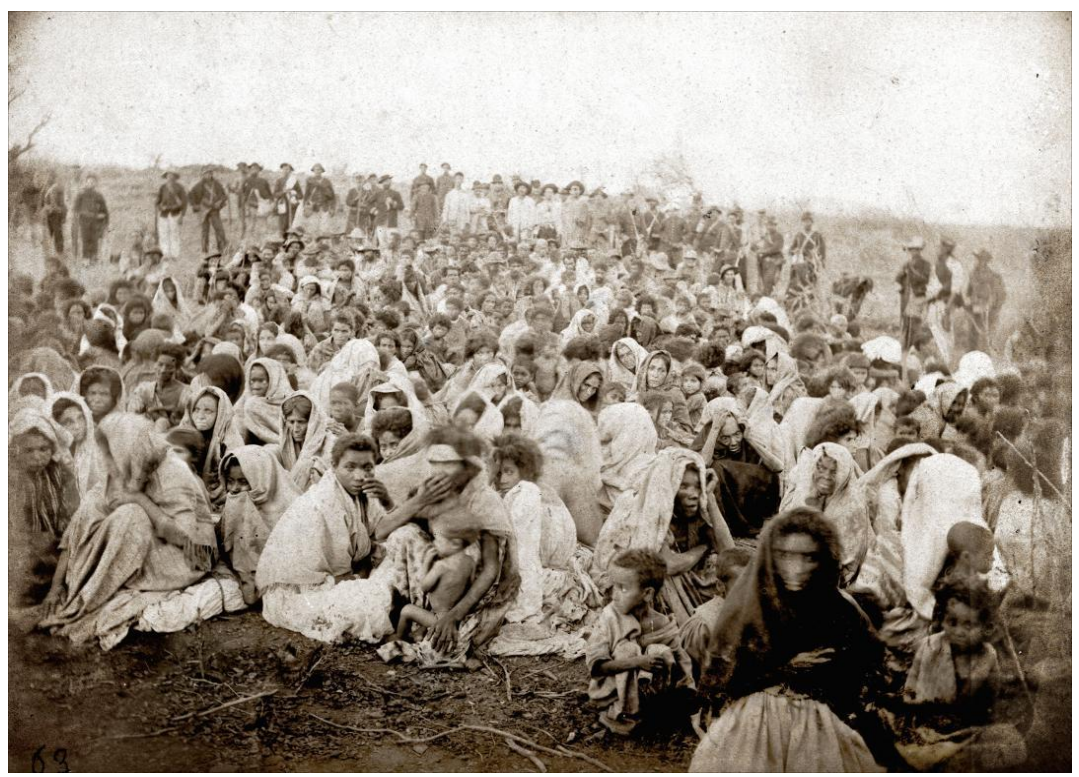

Fonte: Flavio de Barros. 400 jagunços prisioneiros, 2 de outubro de 1897. Canudos, Bahia. Acervo Museu da República. Imagem recuperada digitalmente pelo Instituto Moreira Salles.

Os registros fotográficos capturaram e testemunharam passagens importantes da história brasileira, sobretudo em situações de conflitos e guerras, cujas circunstâncias eram inacessíveis a muitas pessoas. No caso da guerra, a fotografia, enquanto testemunho do referente, retratava a realidade do vivido, para quem estava distante dos campos de batalha. A foto de Augusto Flávio de Barros $^{8}$ retrata a rendição dos conselheiristas em 02 de outubro de 1897, no final da Guerra de Canudos.

Pode-se dizer que a Proclamação da República, em 1889, acentuou as desigualdades econômicas e sociais no país, principalmente, em regiões isoladas, como no interior da Bahia, que, além de vitimadas pela seca, ainda recebiam visitas frequentes de cangaceiros, que saqueavam e matavam a população miserável.

A Figura 2 retrata os sobreviventes da última investida das tropas de infantaria, artilharia e cavalaria contra o povoado de Canudos, comandada pelo general Arthur Oscar de Andrade Guimarães. A imagem é composta por mulheres, crianças e inválidos, que se renderam e tiveram suas vidas poupadas. $\mathrm{O}$ arraial de Canudos chegou a ter perto de 30.000

\footnotetext{
${ }^{8}$ Augusto Flávio de Barros foi um importante fotógrafo brasileiro porque retratou a Guerra de Canudos. Ele foi contratado pelo exército para documentar a campanha de Canudos e documentou os últimos momentos da guerra. Fez um trabalho composto por uma série de 72 fotografias, que constitui um dos mais importantes registros de conflitos armados no Brasil do século XIX. Não se tem dados biográficos dele, mas sabe-se que na última década do século XIX, ele possuía um estúdio de retratos na cidade de Salvador, chamado Photografia Americana. Fonte: BRASILIANA. Guerra de Canudos pelo fotografo Flávio de Barros. Disponível em: http://brasilianafotografica.bn.br/?p=3002. Acesso em: 24 maio 2018.
} 
habitantes. No entanto, o último ataque ao local, que contava com a força de quatro mil homens do exército republicano, foi determinante para destruir completamente o arraial.

A Figura 2 retrata um aglomerado de pessoas, visualmente destacadas por dois grupos. No primeiro plano da fotografia, aparece um grupo maior de pessoas sentadas no chão, vigiadas logo atrás por um grupo de soldados. O que se pode perceber é que esse grupo de sobreviventes, encolhidos e acuados, cobertos por panos, que cobriam feridas e amputações, ainda carrega em seus gestos e expressões faciais a memória do terror da guerra.

O que se pode inferir dos operadores discursivos não verbais (nesse caso o ângulo da câmara) é que o fotógrafo Augusto Flávio de Barros parece estar frontalmente muito próximo dos sobreviventes, e ao manusear a sua câmera, ${ }^{9}$ desperta um único movimento coletivo das pessoas, levando-as a mirar o objeto manuseado pelo fotógrafo. No entanto, como a imagem do exército republicano estava desgastada perante a opinião pública, por não obter êxito nas duas primeiras investidas contra Canudos, o terceiro e o último ataque arrasador precisava, portanto, ser retratado de modo a resgatar a imagem do poderio e a eficiência do exército. Nesse sentido, a posição ordenada e organizada dos sobreviventes, embora dominados e humilhados, seria a prova definitiva da destruição de Canudos e essa seria a imagem que a República passaria para a sociedade civil.

Contudo, a pose forçada, na Figura 2, vela contradições. Nessa fase política conturbada, os militares republicanos detinham o monopólio da informação, que era repassada aos jornais da época, principalmente, o "Estado de S. Paulo", que publicava a versão republicana da guerra. As atrocidades cometidas pelos exércitos republicanos (tortura, estupros, degola de inocentes, esquartejamentos e prostituição, entre outras) vieram à tona a partir da literatura de Euclides da Cunha, em “Os sertões”. Nesse sentido, a cena retratada na foto acima pode muito bem ser uma encenação forçada, haja vista que os homens uniformizados e armados ao fundo são soldados vigiando os prisioneiros.

Nesse sentido, faz-se necessário problematizar o discurso político oficial do governo republicano da época (Prudente de Morais), que se empenhava em noticiar que se tratava de uma guerra contra monarquistas no sertão baiano. É importante observar que as pessoas que aparecem nessa imagem - maltrapilhas, esqueléticas, nuas, castigadas, desoladas - são os derrotados e prisioneiros de guerra, no entanto, mesmo com base na historicidade dos textos oficiais, cabe ao leitor aplicar o princípio da contradição.

${ }^{9}$ Tratava-se, presumivelmente, de uma câmera portátil modelo Kodak, lançada por volta de 1888, que significou um grande avanço para a popularização da fotografia, pois permitiu a simplificação do trabalho do fotógrafo. Disponível em: http://www.scielo.br/scielo.php?script=sci_arttext\&pid=S0104-59701998000400017. Acesso em: 26 maio 2018. 


\section{Considerações finais}

Na confecção desse artigo, procurou-se trazer à tona a questão da leitura da imagem na categoria fonte fotográfica. Além disso, procurou-se fazer a crítica no sentido de que o uso que se faz da imagem na sociedade continua sendo objeto de sistematização da ideologia capitalista, por meio do monopólio e do controle do seu conteúdo e, com frequência, é construída para garantir a perpetuação da cultura do consumo de massa.

Desse modo, o presente trabalho objetivou pesquisar a importância da imagem fotográfica no contexto social, a fim de ampliar e propor algumas sugestões de leitura enquanto fonte documental para compreender a realidade. Além disso, o artigo revelou a necessidade de a educação brasileira, por meio das políticas públicas em educação, repensar a importância de trabalhar com fontes iconográficas e desenvolver a apreciação crítica, reflexiva e problematizadora a partir dessa leitura. A reflexão na construção do texto mostrou que estamos diante de um problema político social importante na educação brasileira: o analfabetismo visual. Nossos professores e alunos não foram emancipados para trabalhar com a natureza heterogênea da imagem fotográfica que forma nosso mundo e que frequentemente é reproduzida como conteúdo de uma ideologia capitalista e mercadológica.

Em face a essa realidade, fez-se o alerta para a necessidade de se criar uma política pública educacional que implemente no currículo dos cursos de licenciatura uma disciplina para ensinar a ler com imagens, sobretudo, para superar a leitura instrumental de caráter positivista e alcançar o nível da crítica e da denúncia.

A proposta de leitura da imagem fotográfica, nesse trabalho, procurou valorizar o seu papel predominante como forma de linguagem que, por ser linguagem, portanto, é ideológica e revela a face da realidade social e histórica da sociedade.

Em face às complexas inquietações que nortearam a produção desse texto e à natureza heterogênea do objeto em análise, decidiu-se trabalhar com uma concepção dialética e dialógica da linguagem e da comunicação, priorizando o aspecto histórico e concreto do tempo, da cultura e das relações sociais, sobretudo, enfatizando que a relação do leitor com a leitura da imagem fotográfica deve ser de aproximação e distanciamento, já que se trata de um objeto com conteúdo metaforizado, silenciado e não fechado. 


\section{REFERÊNCIAS}

BAKHTIN, M.; VOLÓCHINOV, V. N. Marxismo e filosofia da linguagem: problemas fundamentais do método sociológico na ciência da linguagem. Trad. Michel Lahud e Yara Frateschi Vieira. 8. ed. São Paulo: Oscite, 1997.

BARROS, D. L. P. de. Contribuições de Bakhtin às teorias do texto e do Discurso. In: FARACO, C. A.; TEZZA, C.; CASTRO, G. de. Diálogos com Bakhtin. Curitiba: UFPR, 2001.

BRASILIANA. Guerra de Canudos pelo fotógrafo Flávio de Barros. Disponível em: http://brasilianafotografica.bn.br/?p=3002. Acesso em: 24 maio 2018.

CHAUÍ, M. O que é ideologia. São Paulo: Brasiliense, 1983.

CIAVATTA, M. O mundo do trabalho em imagens. Rio de Janeiro: DP\&A, 2002.

DUBOIS, P. O ato fotográfico e outros ensaios. Campinas: Papirus, 1998.

DUCROT, O. O dizer e o dito. São Paulo: Pontes, 1987.

ECO, U. Apocalípticos e integrados. São Paulo: Perspectiva, 1976.

FLUSSER, V. Filosofia da caixa preta. São Paulo: Hucitec, 1985.

FOUCAULT, M. Do governo dos vivos: curso no Collège de France, 1979-1980 (excertos). Trad. Nildo Avelino. Rio de Janeiro: Achiamé, 2010.

GADOTTI, M. Concepção dialética da educação: um estudo introdutório. São Paulo: Cortez, Autores Associados, 1990.

HUBERMAN, G.D. O que vemos, o que nos olha. São Paulo: Editora 34, 1998.

JOLY, M. Introdução à análise da leitura da imagem. Trad. Marina Appenzeller. Campinas, SP: Papirus, 2005.

KOSSOY, B. Fotografia \& história. São Pulo: Ateliê Editorial, 2001.

MARX, K. O capital. São Paulo: Abril Cultural. Coleção os Economistas, 1985.

MAUAD, A.M. Poses e flagrantes: ensaios sobre história e fotografia. Niterói: UFF, 2008.

MERLEAU-PONTY, M. Fenomenologia da percepção. Rio de Janeiro: Freitas Bastos, 1971.

METZ, C. et al. A análise das imagens. Petrópolis: Vozes, 1973.

MÓRAN, J. M. Leituras dos meios de comunicação. São Paulo: Pancast, 1993. 
MORIN, E. Os sete saberes necessários à educação do futuro. TV Cultura, São Paulo, 2000. (Entrevista). Disponível em: http://www2.tvcultura.com.br/rodaviva/lancamento-memoriarodaviva.asp. Acesso em: 20 mar. 2019.

OLIVEIRA, M. A. Dialética hoje: lógica, metafísica e historicidade. São Paulo: Edições Loyola, 2004.

ORLANDI, E. P. Leitura: perspectivas interdisciplinares. São Paulo, Ática, 1995.

ROITBLOG. 2008. Disponível em: http://roitblog.blogspot.com.br/2008/. Acesso em: 20 maio 2018.

ROUILLÉ, A. Entre documento e arte contemporânea. São Paulo: Senac, 2009.

SCHLICHTA, C. Arte e educação: há um lugar para a Arte no ensino médio? Curitiba: Aymará, 2009.

SOULAGES, F. Estética da fotografia. São Paulo: Senac, 2010.

SOUZA, T. C. C. Análise do não verbal e os usos das imagens nos meios de comunicação. Niterói: Ciberlegenda UFF, 2001.

TORRALVO, I. F. Linguagem em movimento. São Paulo: FTD, 2010.

\section{Como referenciar este artigo}

PASSOS, E. R.; VIEIRA, A. M. D. P. A educação brasileira e a cultura fotográfica: para além da impressão. Revista Ibero-Americana de Estudos em Educação, Araraquara, v. 15, n. 4, p. 1799-1823, out./dez. 2020. e-ISSN: 1982-5587. DOI: https://doi.org/10.21723/riaee.v15i4.13145

Submetido em: 21/11/2019

Revisões requeridas em: 24/02/2020

Aprovado em: 30/06/2020

Publicado em: 30/08/2020 
